\title{
COMPARATIVE STUDIES IN
}

SOCIETY

AND

\section{HISTORY}

An International Quarterly

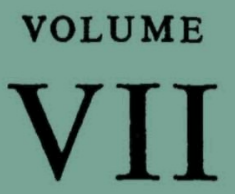

NUMBER 4 - JULY 1965

MOUTON \& CO - PUBLISHERS

THE HAGUB - NETHERLANDS 


\section{CONTENTS}

\section{The Making of Entrepreneurs}

LEONARD KASDAN, Family Structure, Migration and the Entrepreneur

Two Patterns in the History of Bureaucracy

Cho-Yun Hsu, The Changing Relationship between Local Society and the Central Political Power in Former Han: 206 B.C. 8 A.D. . . . . . . . . . . . . .

Alan B. SPITZER, The Bureaucrat as Proconsul: The Restoration Prefect and the police générale. . . . . . . .

States and Societies

Karl W. Deutsch and Hermann Weilenmann, The Swiss City Canton: A Political Invention . . . . . . . . . 393 Aharon Ben-AmI, Institutional Lag and Neofunctions: the Case of the Latin Kingdom of Jerusalem . . . . . . . 409

\section{A Dual City}

JANET ABU-Lughod, A Tale of Two Cities: the Origins of Modern Cairo . . . . . . . . . . . . . .

Gerald Breese, Some Notes on a Case Study of European Urban

"Transplants" in Cairo . . . . . . . . . . . 458

\section{Sacral Kingship}

B. G. HaYcock, The Kingship of Cush in the Sudan . . . . 461

Subject Index to Volume VII . . . . . . . . . 481

\section{Editorial Office}

Department of History, University of Michigan, Ann Arbor - Mich., USA.

\section{Subscription}

Comparative Studies in Society and History appears four times a year. Annual subscription $\$ 6.00$ (U.S.A.) or 22 Dutch guilders (or the equivalent in other currencies) payable through booksellers, through the Editorial Office, Department of History, University of Michigan, Ann Arbor, Michigan, or directly to the publisher: Mouton and Company, The Hague, The Netherlands. (N.B. Two years subscription rate $\$ 11.00$ or the equivalent, three years' subscription rate $\$ 15.00$ or the equivalent. Checks should be payable to Mouton and Company.)

(c) Copyright 1965 by the Society for the Comparative Study of Society and History 


\section{COMPARATIVE STUDIES IN SOCIETY AND HISTORY}

VII 


\title{
COMPARATIVE STUDIES
}

\author{
IN \\ SOCIETY \\ AND \\ HISTORY
}

An International Quarterly

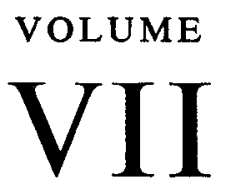

1964-1965

MOUTON \& CO - THE HAGUE 
(C) Copyright 1964 by the Society for the Comparative Study of Society and History 


\section{EDITORIAL COMMITTEE}

L. A. Fallers

Albert Feuerwerker

RAYMOND GREW

G. E. VON GRUNEBAUM

Everett C. Hughes

EDWARD SHILS

ERIC R. Wolf

FREDERICK WyATT

Sylvia L. Thrupp (Editor)
Anthropology

Chinese Studies

History

Islamic Studies

Sociology

Sociology

Anthropology

Psychology

Economic History
Chicago

Michigan

Michigan

California

Brandeis

Chicago

Michigan

Michigan

Michigan 


\section{CONTENTS}

ABU-LUGHOD, J JNET

BAZANT, JAN

Ben-Ami, Aharon

BENDA, HARRY J.

Breese, Gerald

Brunt, P. A.

DEUTSCH, KARL W. and HERMANN WEILENMANN GHOSH, OROON K. Goodrich, CARTer HAYCOCK, B. G. Hsu, CHO-YuN

JASPAN, M. A.

KasDan, Leonard

Keniston, Kenneth LeV, Daniel S.

LeV, Daniel S.

LIFTON, ROBERT JAY

Menashe, Louis
A Tale of Two Cities: The Origins of Modern Cairo 429-457 Evolution of the Textile Industry of Puebla: 1544-1845

55-69

Institutional Lag and Neofunctions: the Case of the Latin Kingdom of Jerusalem 409-428 Political Elites in Colonial Southeast Asia: an Historical Analysis

233-251

Some Notes on a Case Study of European Urban "Transplants" in Cairo

458-460 Reflections on British and Roman Imperialism 267-288

The Swiss City Canton: A Political Invention

393-408

Some Theories of Universal History Argentina as a New Country 70-88 The Kingship of Cush in the Sudan 461-480 Changing Relationship between Local Society and the Central Political Power in Former Han 206 B.C. - 8 A.D.

358-370 In Quest of New Law: The Perplexity of Legal Syncretism in Indonesia

252-266 Family Structure, Migration and the Entrepreneur 345-357 Accounting for Change 117-126 The Politics of Judicial Development in Indonesia 173-199

Rejoinder 202 On Psychology and History: Further Comment 127-132 Historians Define the Baroque: Notes on a Problem of Art and Social History 
NASH, GARY B.

The Philadelphia Bench and Bar, 1800-1861

203-220

Pasti, George, JR.

Comparative Studies of East Asian and West European History: Some Topics and Problems

102-113

Schneider, Harold K. A Model of African Indigenous Economy and Society

Sio, Arnold A.

Interpretations of Slavery: The Slave Status

289-308

SpItzer, Alan B.

The Bureaucrat as Proconsul: The Restoration Prefect and the police générale

371-392

Symmons-Symonole- Nationalist Movements: An Attempt at a ComWICZ, KonstaNTIN parative Typology

221-230

Von Mehren, Arthur

TAYLOR

Comment on "The Politics of Judicial Development in Indonesia"

200-201

Weilenmann, Hermann

see Deutsch

\section{REVIEWS AND REVIEW ARTICLES}

DOVRING, FOLKE

FlinT, JoHN T.

FORSTER, ROBERT and

R. BURR LITCHFIELD

Galanter, Marc

Hirshler, ERIC.

LITCHFIELD, R. BURR see FORSTER

Low, D. A.

SMITH, DONALD E.

Thrupp, Sylvia L.
Bondage, Tenure, and Progress: Reflections on the Economics of Forced Labor

309-323

Review of Donald Eugene Smith, India as a Secular State

160-165

Four Nobilities of the Old Regime

323-332

Review of Donald Eugene Smith, India as a Secular State

133-159

Review of Jaquetta Hawkes and Sir Leonard Woolley, eds., Prehistory and the Beginnings of Civilization

89-97

Studying the Transformation of Africa 21-36 Secularism in India: a Rejoinder 166-172 Review of Louis Gottschalk, ed., Generalization in the Writing of History

98-101 